\title{
CITIZEN'S VOICE ON LOCAL CYBERMEDIA BALEBENGONG
}

\author{
Cendera Rizky Anugrah Bangun \\ Fakultas Komunikasi, Jurusan Komunikasi, STIKOM London School of Public Relations \\ Jl. KH Mas Mansyur Kav 35, Sudirman Park, Jakarta Pusat \\ cendera.r@lspr.edu/cendera.rizky@yahoo.com
}

\begin{abstract}
The development of technology has played a big role to citizen journalism. Balebengong is an example of Local cyber citizen journalism media. The purpose of this research was to understand how the practices of the public sphere in the local cyber media Balebengong. The used theories in this research were citizen journalism and the public sphere. With interpretive paradigm and qualitative method, this research used interview and online data. The object of research was local cyber media Balebengong and key informant who were the contributor and editor of Balebengong. The implications of this research were expected to provide inputs for traditional media in providing more public space portion citizen journalism or more so that the public could also participate in the nation. The result of this research is Balebengong has provided enough public spheres for the members of its society to contribute to it.
\end{abstract}

Keywords: citizen journalism, public sphere, local cyber media, Balebengong

\section{INTRODUCTION}

Technology development contributes to the existence of citizen journalism. Citizen journalism is a journalistic practice done by citizen or non-professional by using video, writing, or pictures as their report tools. McQuail (2005) has said that innovation always comes and is adapted from human needs for social change in the society. Any change within the society will influence the technology and furthermore in the way how communication technology adapted that change.

Setianto (2010) has stated that the mass media is often thought as a capitalist tool. It operates in a capitalist way. Mass media is considered as only try to produce more profit and has the lack of supportive to public interest. So, it is very reasonable to put in doubt if the media gives its space for fulfilling the idea of the public sphere. As stated in the research done by Muhajir and Sumberdana (2012), citizen journalism has become the balancing power of mainstream media. Citizen journalism is one of the answers of media elite in mainstream media, which most of the time publish elitist issues and because of the complexity of the rules to produce news in media mainstream. In mainstream media, the citizen is usually only viewed as a news object. Based on this kind of thought, Balebengong was found. When first made on 4 April 2007, initially in the form of a subdomain blog at Blogspot, domain and hosting service provider with Google's free. On May 5, 2007, this blog began to use their domains in www.BaleBengong.net until today. Citizen journalism through the media, BaleBengong manager, tries not only to invite people to write but also to provide a place for people to share information from and about the people. The media has also become a kind of storefront where the writings of some Bali bloggers scattered then displayed again in BaleBengong.

Balebengong is a local cyber media that based in Bali. It has the tagline "Media Warga Berbagi Cerita" (Citizen's media to share a story); this local media accommodate public's needs of information. In Balebengong, public does not only get the news but also give the news. The target 
market for Balebengong is already segmented; it is for middle urban class and educated people. Balebengong has its own place in the middle of the triangle between public, state, and capital. Balebengong was established by Sloka Institute as alternative media (citizen's voice) from any of the mainstream that already existed in Bali that tend to become uneven when they share information. The display of of Balebengong website can be seen in Figure 1.

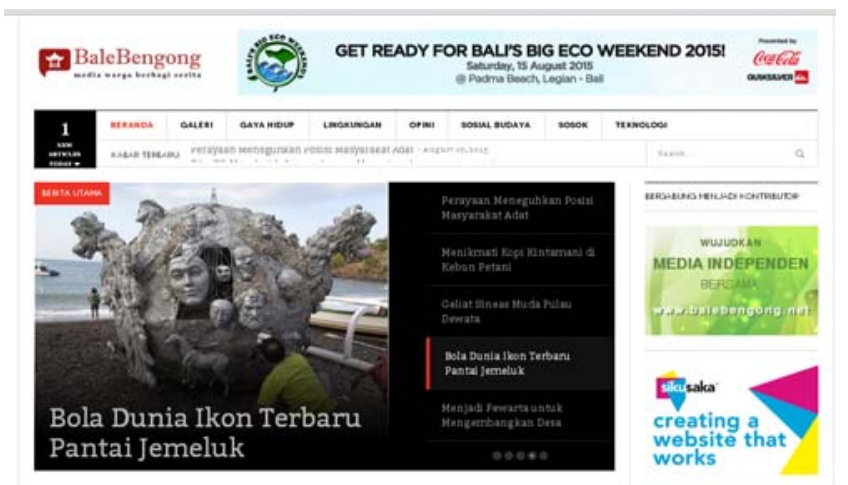

Figure 1 Website Balebengong.net

(Source: Balebengong, 2015)

At first, the one that manages this blog was Sloka Institute, a non governmental organization in Bali that specialized in the development of media, journalism, and information. After that, Bali Blogger Community help to manage this blog, the community is more focused on programming.

According to Muhajir and Sumberdana (2012), the Sloka Institute is more focused on editorial aspects like writing, editing, and also giving journalism training to the public or the community. As for now, there are eight blog's admins from any kinds of expertise; they are the journalist, nongovernment organization activist, public, information technology expertise, and blog designer. Using the genre of citizen journalism in managing the blog, Balebengong invites the public to share information to and through this blog. The public can share by text, photo, or video; so that the public become not only the consumer but also the producer of their own information. Media can create public opinion from the news that they published. It will become very dangerous if the audiences do not understand the news, or not literate enough, yet the media lead the public opinion about an event. That is why it is important for the public to get information not only from the mainstream media but also become a producer of its own news.

By carrying out the principle, "Because Freedom of Information is Human Rights", it can not be denied, the news contained in Balebengong is not the only news that comes from the particular group. Some of the articles that contained in the site Balebengong.net, for example, "Never Give Up on Refusing Reclamation", or "Being a Smart Consumer for the Sake of the Environment," or "Give Rehabilitation and not Iron Bars", "Campaigned Values Anti-Corruption through Film", and " Bali Diamond Women PLWHA Glow " show a lot of things or information that can be given to the citizens of the side that is rarely raised by the major media, or normally only used as a feature. In Balebengong, the articles are also many positive themed appointed as a form of freedom of information itself. Jargon that "bad news is good news" does not apply in this local cyber media. Any information, any news is good news and has its own value. Public's voice channeled through cyber media need not be concerned with economic interests, power, ideology, and the amount of circulation or sale. The purpose of the public sphere is to make people able to reflect themselves critically, both politically-economically and culturally. However, Habermas (1991) has realized there is no aspect of life that is free of interest, even science. Space free from domination, in which everyone has an equal 
opportunity to participate in decision-making, is the ideal structure. He has believed that a strong public space, separate from personal interests, is needed to ensure the achievement of this state.

This leads to the question, does Balebengong provide enough space for its society member to contribute in the news making and sharing? The purpose of this research is to understand how the practice of public sphere in the local cyber media Balebengong is. Figure 2 shows the contributor page of Balebengong, while Figure 3 shows the example of the article in Balebengong.

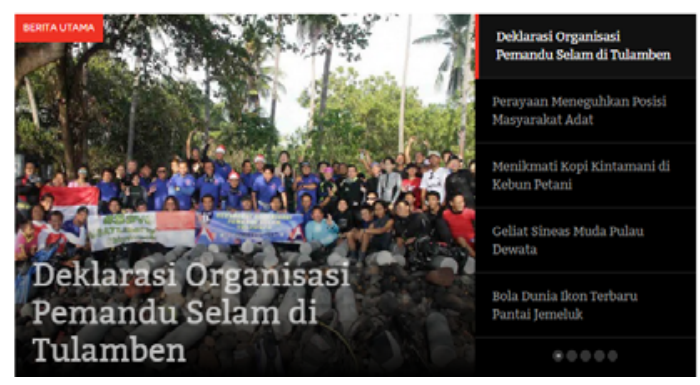

Figure 2 Contributor Page

(Source: Balebengong.net, 2015)

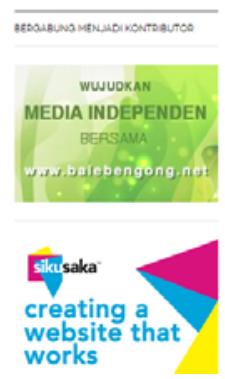

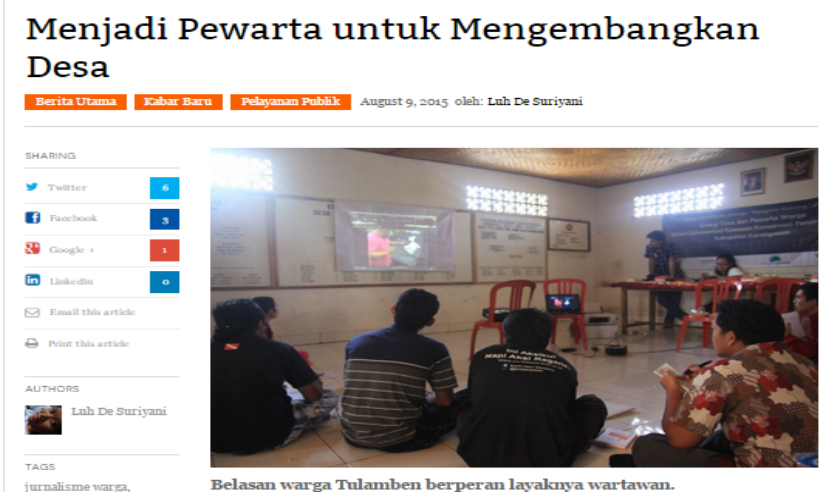

Figure 3 Article in Balebengong.net (Source: Balebengong.net, 2015)

\section{METHODS}

This research uses interpretive paradigm because the purpose of this study is to understand the problems. This study uses qualitative approaches to data collection. The first phase done by interview is the key informant for and the second stage is using literature data as secondary data. The object of research is local cyber media Balebengong and a key informant who is the contributor and editor of Balebengong. According to Baxter and Babbie (2004),

"The interpretive paradigm encompasses the broad range of orientations, each with its own historical roots. However, in general, researchers who embrace the interpretive tradition believe that human action stands apart from the rest of the physical and biological world because of the reflective capacity of human beings." 
The researcher believes that human action is purposive; the action is intended to accomplish some purpose. Just like the statement earlier, this kind of paradigm is giving meaning to human action. In qualitative research, the primary research instrument is the researcher (Baxter \& Babbie, 2004). Although the researchers (of this method) describe how they gathered their data, the goal is not one of positioning the reader to replicate the study. The challenge is how they tell the story of what they have learned. That is why in this research, the informant used only from the contributor and editor from Balebengong because he is considered as the key informant of Balebengong.

In qualitative research, the primary research instrument is the researcher (Baxter \& Babbie, 2014). The challenge is how they tell the story of what they have learned. As stated by Lindlof (1995),

"To the analyst, documents are very important because they are the "paper trail" left by events and processes. Documents indicate, among other things, what an organization produces and how it certifies certain kinds of activities, categorizes events, or people, codifies procedures or policies, instructs a readership, explains the past or future actions and tracks its own activities."

A concept of Galtung's Triangle theory first was introduced by Johann Galtung in 1999. By carrying out the triangles, the three elements are in the State (country), Capital (private), and Civil Society (society). Then where the media lies? In democratic countries, the media should be in the middle. Galtung (1999) puts the media in the middle, between these elements, assuming the media should be neutral and not take sides or leaning to either side. Based on this model, there is an area between the media and civil society there must be a reciprocal of the media to civil society, that's where public space located. This scheme can be seen in Figure 4.

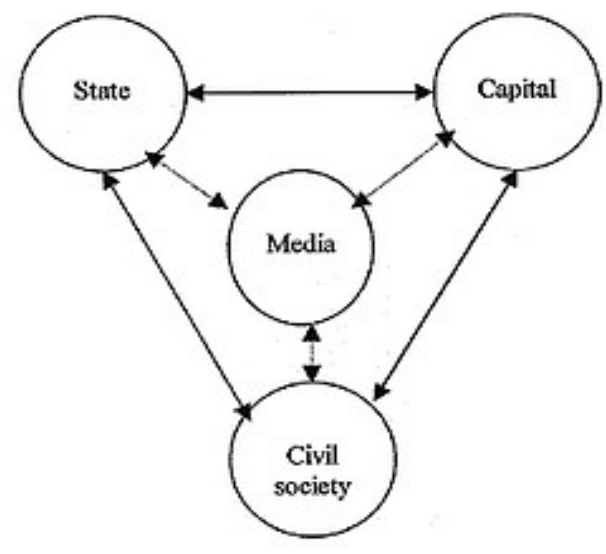

Figure 4 Galtung's Triangle

(Source: Galtung, 1999)

Public sphere comes from an essay Jurgen Habermas in 1962 entitled "The Structural Transformation of the Public Sphere". In that essay, Jurgen Habermas (1991) has stated that the development of the social area that is free of censorship and domination. The region is called a "public sphere", for example, all areas of social life that allow us to form a public opinion that is relatively free.

The public spaces provide social practices, politics, and culture that are in open discussions to discuss the problems of general social interest. The emphasis on formation sensitivity (sense of public), with its proximity to the public, the public sphere is intended as a public sphere, where the general public can practice their right to have a discussion or voicing their opinion. The purpose of the public sphere is to make people able to reflect themselves critically, both politically-economically and culturally. However, Habermas realizes there is no aspect of life that is free of interest, even science. 
Space free from domination, in which everyone has an equal opportunity to participate in decisionmaking, is the ideal structure. Habermas (1991) believes that a strong public space, separate from personal interests, is needed to ensure the achievement of this state. With this thought, the researcher wants to see whether the practice of public sphere is free from the domination of the ruling manifest in the local cyber media Balebengong.

Citizen journalism is a journalistic activity undertaken by ordinary citizens (non-professional). The concept of citizen journalism is based on communities (public citizens) who have an active role in the process of collecting, reporting, analysis, and dissemination of news and information. News or information is produced by citizen journalists disseminated through various media, both mainstream media that provides a space of citizen journalism and the media owned by residents themselves, such as the blog, magazines, newsletters, community radio, etc. As the media literacy is improved, it is also influenced the development of citizen journalism. Also, the rapid innovation in the field of information technology also affects the interest of citizens in the journalistic activities (Suparyo, 2011).

Allan and Thorsen (2009) have stated that citizen journalism is a phenomenon of the rights they have. Mark Deuze in Allan and Thorsen (2009) has mentioned that citizen journalism could be defined as public, who are usually just as the audience, using the tools of the press that they have to inform the other residents. Monaghan and Tunney (2010) have stated that the presence of citizen journalism, participatory media shows how informative alter the relationship between traditional media with their audience. The assumption is that there is a flow of information previously only from the media to the public that turned into an active democratic dialogue among community members.

Bentley has stated in Allan and Thorsen (2009) that Citizen Journalism exists as the counter of discourse established by the mainstream media. The dissatisfaction of this mainstream media turns into strength. This strength increases with the development of ICTs to enable more people to become producers of information. The existence of New Media, which is a product of the development of ICT blurs the dichotomy between the media and the audience. Website presence challenges the paradigm of traditional media by allowing the reader to be a writer (Lindawati, 2014). Herman in Suparyo (2011) has argued the emergence of citizen journalism can shift the way the world of journalism. In the policy mainstream media, citizens only become the object of preaching. In the citizen journalism, the boundary between producers and consumers of information are difficult to separate, because the citizen is a producer and connoisseur of the information itself. Herman added that the journalist and the reader are not only a producer and consumer, but there is social solidarity.

\section{RESULTS AND DISCUSSIONS}

The numbers of internet and social media users in Indonesia has increased. This escalation coincided with the country's transition to democracy in 1998. Before 1998, the media was regularly watched by the government. But after the Freedom of the Press (marked by UU Pers no.40/1999) stated that press is independent, and the government will no longer intervene the press. Numbers of media are increasing, not only newspapers or television but also digital media. The growth of the media is the good thing in democracy era, it indicates the freedom of speech, where people finally have their own public sphere without fear of getting captured or imprisoned. Since 1999 until now, the technology has developed from the very simple one to the most sophisticated one. As globalization emerged and Indonesia is quite open with the culture from outside, no wonder there are a lot of media or digital media in Indonesia (either it is locals or international ones). Based on the latest data from national research conducted by APJII and PUSKAKOM UI in 2014, from 252, 4 million citizens in Indonesia, there are 88,1 million internet and social media users. This means the internet penetration is 34,9\% (APJII, 2014). 
The use of internet gives a place for the citizen journalism to play its role in the society itself. For Balebengong, this means the opportunity to become the local voice for the people. It can be seen the mainstream media in Bali, in the segment of the daily newspaper in Bali is the Bali Post, Denpost, Bisnis Bali, Nusa Bali, Radar Bali, Bali News, Dawn Bali, Bali newspapers, and Patrol Post. Bali Post, Denpost, and Bisnis Bali are in the group that Bali Post Media Group. Meanwhile, another newspaper published each company. Based on the total circulation, Bali Post is the greatest media followed Denpost, Nusa Dua, Bali Radar, and Warta Bali.

According to data from Indonesia Media Guide 2004 published by the Association of Indonesian Advertising (GN), Bali Post controls 31,5\% of readers in Bali, Denpost 19\%, Jawa Pos $7,8 \%$, Nusa (before it changed its name so Nusa Bali) of 6,8\%, Radar Bali 4,7\%, the Bali Aga 2,7\%, Kompas $1,6 \%$, and Warta Bali $1 \%$. This data is obtained from a population of 485.000 . A year later the data is not much different with Bali Post controls 33,5\%, Denpost 19,1\%, Jawa Pos 8,5\%, Nusa Bali 8,1\%, Radar Bali 4,6\%, Kompas 3\%, and Warta Bali 0,6\%. It can be seen in Figure 5.

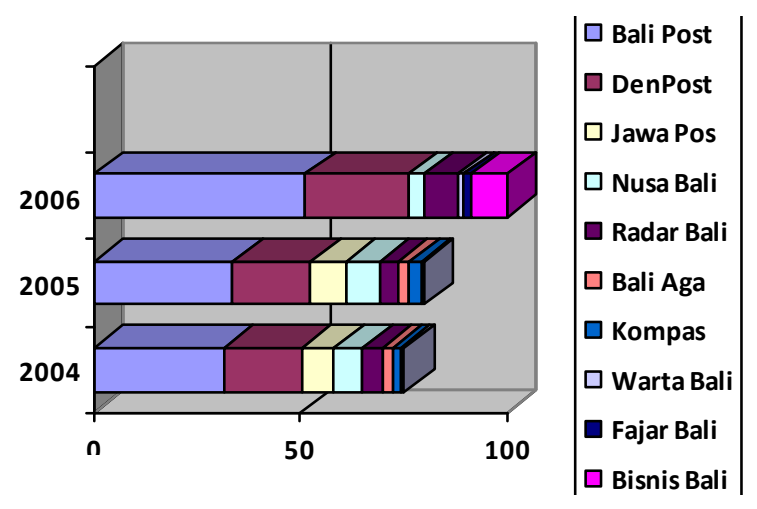

Figure 5 Media Chart in Bali year 2004 - 2006

(Source: Muhajir, 2007)

The following data is newspaper circulation in Bali by I Made Santra (2006). Bali Post 87500 copies (51,17\%), Denpost 42500 copies (24,85\%), Nusa 7000 copies (4,09\%), Radar Bali of 14000 copies (8,19\%), Warta Bali 2500 (1,46\%), Fajar Bali 2500 copies (1,46\%), and Bisnis Bali 15000 $(8,77 \%)$.

In Post-reformation, according to Chairman of AJI Denpasar Rofiqi Hasan on interviews (Muhajir and Sumberdana, 2012), media in Bali is growing rapidly but the information is less variation. Sources of information media and journalists are still dependent on government and bureaucracy. On the other side of the information, society is still small. Thus there are two different views on the quality of media content, and some say already diverse and appropriate rules of journalism, but more are also saying the media in Bali is still less diverse contents. However, if you see at a glance the contents of the news media, it appears that the content of the media is less diverse both in terms of themes or speakers. Lack of diversity in mainstream media contents in Bali, especially online and daily, may occur as a result of the work patterns of journalists themselves. Most journalists are working in government offices, such as governor and the parliament, the police, hospitals, so that they are the same resources. As a result, news items and sources are almost the same.

Researchers conducted interviews with Anton Muhajir as the administrator and editor of cyber media Balebengong. He has mentioned that citizen journalism could be present because there is the chance for progress in information technology such as the Internet. Therefore Balebengong presents to provide space so that citizens could also be involved in the production process of information: "Not 
only as an object but also the subject of information, especially in the news media. First, they act as a consumer. Not only read but also to divide or leave a comment. Second, as the producer of the information itself."

Muhajir said the works system in Balebengong. He has stated that Balebengong works entirely for the citizens and do not represent the company, group, or political interests of anyone, and is open to everyone. Every citizen has an equal chance to be heard and spread his voice. BaleBengong provides special spaces for citizen engagement. In addition to passing the information in different formats such as text, images, audio, or video, there is also a comment field so that residents can discuss there. Other space through social media, especially Twitter. Although Balebengong also has a Facebook Page, there is not too much discussion. Unlike in the bustling Twitter, it will get feedback from the community, for example, is when people want to complain about public services, especially in Bali is not maximized, or would like to comment on an issue and a topic that is growing. When viewed from the side of the topic, Balebengong open to any topic as long as relevant to Bali, because BaleBengong itself is a community media in Bali. However, when viewed in general does the topic of environmental, social, cultural, and lifestyle. There are almost no topics about the economy or sports in articles. From the information format is most text and photos, and sometimes video.

\begin{abstract}
"We try to be different from the media discourse, topics, viewpoint, storytelling, or its format. We do not follow the mainstream, for example by simply pursuing the number of visitors through the new news and sensational. Let's just say we use the slow style of journalism. Let be slow but accurate."
\end{abstract}

Muhajir has stated that Balebengong provides the space for public to express their opinion without force them to use the common journalist style. Online journalism usually counts on the speed and ignores accuracy, but slow journalism style is used in Balebengong. Quoted from Tempo.com, Nezar Patria as a member of the board of ethics of the Press Council states that, speed and accuracy are key issues in online media or cyber media. However, Nezar Patria reminded that demands the immediate presentation of news online and in real time it is not used as a justification for the loading of the news is not accurate and credible (Yunni, 2013). According to Nezar, now there are some misperceptions among managers and journalists of online media. The mistaken perception, among others, online journalism is not serious, as the main achievement of guided traffic sensational news, and the quality and credibility of online news is lower than print journalism. Depth coverage does not have a place, especially investigative reporting. As a result of this thinking, the news in online media in Indonesia, trap in the shallow news and rebranded as second-class news. This occurs because the online media competition to reach traffic. At the same time, he said, the online advertising market in the world because it uses a fairly brutal advertising system based on traffic. In fact, according to Nezar, online media in US and Europe always maintain the accuracy even though they have to keep up the speed. Nezar gives an example like online media Huffingtonpost.com. This media at first is a blog, but then manage to be online media and the news has the great accuracy (Yunni, 2013).

In Balebengong, society is not only a receiver of the information but also as producers of information. The term is "from the citizens for the citizens". Mentioned by Muhajir that every citizen is a reporter, so that the community also to contribute to the sustainability of this medium. The target audience for Balebengong is public urban middle class and educated. When viewed from the data released by Google Analytic, it is demographics, visitor BaleBengong is 54,15 \% male and 45,85 \% female, and 33,5 \% aged 25-34 years, $27,5 \%$ of 18 -24-year-old, $15,5 \%$ of $35-44$ years-old, $12,5 \%$ of 45-54 years-old, and the remaining 55 years old and over, in terms of socioeconomic class, mostly among the urban middle class. This is consistent with the main target of Balebengong who used this as an alternative media.

However, if Balebengong is considered sufficient in providing information to the people of Bali, the answer is no. Balebengong does not focus on the actual issues at the mainstream media; it's 
limited just to information about public services, information simple things like phone numbers taps, blood donor program, etc. For the people who inquire via Twitter, then Balebengong is quite informative. In addition to the website address is at www.Balebengong.net, the Twitter account is @balebengong, and Instagram is @balebengong in meeting the information communication process of interaction between the citizens and the media. Sometimes the post contains different information from the website. In the website is about news articles, at Twitter is a forum for interaction and information, and in the Instagram shows the various activities undertaken by Balebengong with the surrounding community. For example, in one article entitled "Creating a More Friendly Disabled Home", before rising in articles, it is already published the photos in the Instagram account Balebengong. So that, the reader can feel the involvement in the process of making the article. It shows that there is engagement given by the media to the audience. Figure 6 shows the depiction of Instagram account of Balebengong, while Figure 7 shows the depiction of Twitter account of Balebengong.

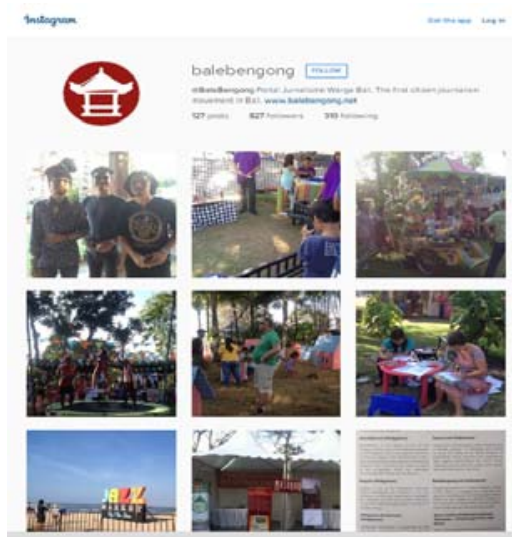

Figure 6 Instagram Account of Balebengong (Source: Instagram, 2015)
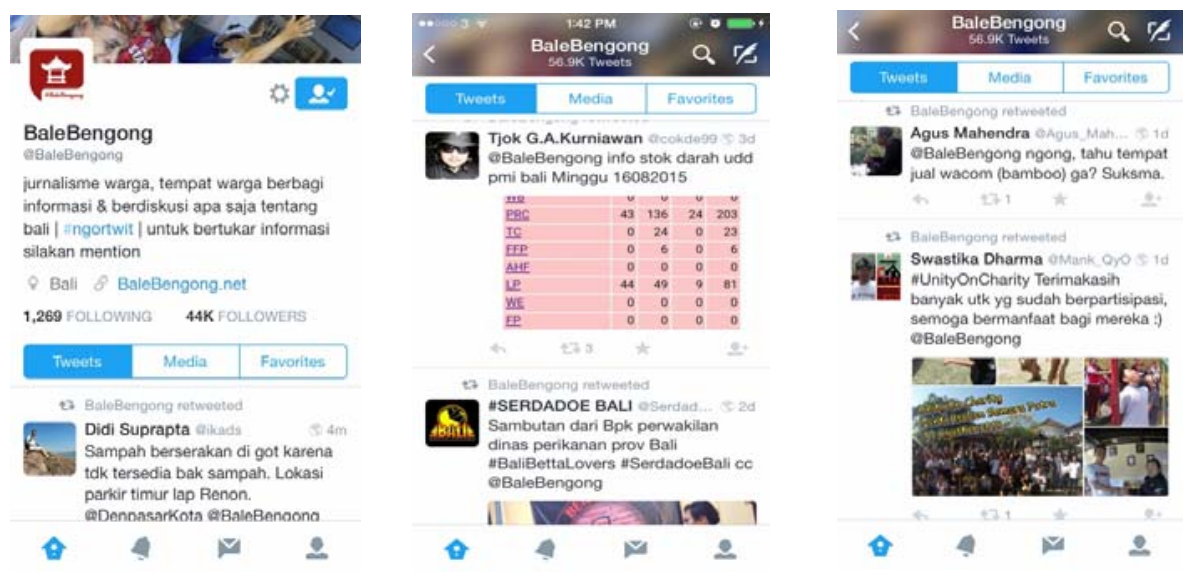

Figure 7 Twitter Account Balebengong

(Source: Twitter, 2015) 
Balebengong is allegedly an alternative voice of citizens, regarding the statement from the informant he explains,

"Briefly as citizens so have the media to speak out, including on controversial issues such as reject reclamation in Bali Benoa Bay. There is a media where they can speak directly about specific issues. In other cases ever existed, such as the feud between Governor of Bali by Bali Post, the residents also do not get stuck on the support of one of them but could determine his own attitude."

Here, people become educated for their assertion that they are not merely passive recipients of information; they should also be active and participatory to information. They do not just accept and swallow the information received, but being the smart reader.

"First, that the citizens can also become producers of information. They do not depend on journalists. Let them produce the information themselves. Besides being able to be more accurate because it comes directly from the source as well as for the information chain is not getting longer. It is from citizens directly to the citizens. Second, be critical of the media. Sometimes the news is no discussion about a particular issue. So we expect the citizens to understand better journalistic ethics, professionalism in the media, or how to become a newsreader critical. Third, learn to share and debate. Either it is writing or commenting on social media."

Regarding the protection of information, identity, and privacy of citizen journalism actors explained that there is no special protection. Since the beginning has been made clear that the risk and responsibility are on each of these media writers of citizen journalism. Therefore, each contributor was asked to be open about his identity.

\footnotetext{
"There were one or two who use aliases, but as admin, we know their true identity. Although there is no specific protection, ethically, we will still help them if there is a problem. Once there was a case where one of our contributors are required to police to know. We provide assistance. His case ended peacefully. The same support will be given to another netizen in Bali if facing problems related to freedom of expression in cyberspace, and we know about the case. It demonstrates our commitment to supporting freedom of expression, including what we do through the medium of citizen journalism. "
}

Regarding this, how about ethical violations in this medium? Apparently, in this alternative media, ethics remain prioritized. Despite being an alternative media that are online, Balebengong does not necessarily forget the ethics; the benchmark used as a reference is the Media Coverage Guidelines Siber. Thus, although the majority of contributors Balebengong not professional journalists, they are still bound by netiquette, a common ethics in cyberspace. As long as the articles not violate certain Gender, Religion, Race.

As a local cyber media, Balebengong is quite serious about its role in society. Each article passes through a process of screening and editing, as well as in the major media. For information provided by citizens will also be seen from the information whether reasonable or not, of the editors will do a check and re-check or news crosscheck whether the information is correct or not. This is done to ensure the accuracy of the news. According to him, most commonly when citizens send information or images that are sensitive to Balebengong Twitter account. He further said that the people already have a desire to contribute in good citizen journalism, rather than nothing at all he said. Citizens are becoming increasingly active and willing to speak differently from the way the mainstream media perspective. However, it still needs more and more people are involved so that maximum use of public space, in this case, public space is a local cyber media Balebengong. 


\section{CONCLUSIONS}

Emerging as a counter of the mainstream media, the big idea of the existence of Citizen Journalism is that people without formal education in journalism, can use modern technology, especially the development of ICT to produce messages, the fact in independently or together (sharing) with others. These conditions provide opportunities for the community to play a role in the 'battle' discourse in the public sphere. Bowman and Willis have defined Citizen Journalism as a state where citizens have an active role in collecting, reporting, analyzing and distributing news and information (Lindawati, 2014). Encouraging citizens to play an active role as a democratic society, not just to receive messages but to help spread the message; Balebengong provides concrete action for the people of Bali. The function of public space conducted by Balebengong is already pretty well done by this medium. In social media accounts on Twitter, for example, every question will be answered by admin Twitter Balebengong about public service or if there is movement or activity in Bali and beyond who wants to help spread the word (Balebengong followers retweet to others).

There are two main controls of citizen journalism; the first of the rules governing the activities of the press, the second is the community itself. Presented by Suparyo in the book "citizen reporter" that citizen journalism should also be subject to the applicable code of journalistic ethics. Why is that? This is to gain the trust of the community that the news generated is trustworthy, objective, and independent. In fact, citizen journalism is usually for those in favor of the citizens, because the mainstream media also recently tended to certain parties only. Nevertheless, every citizen who wants to become a contributor in Balebengong will be equipped with the Guidelines for Media Coverage Siber and every article that entry will be moderated as well as through the screening process so not all articles directly loaded or loaded feasible.

In terms of delivery of the article, though already quite a lot of people who have contributed in sending the article, but according to Anton, to invite more and more people to be involved. So the function of this public space can be maximized. Seen from many citizens who contribute less topic, making the Sloka Institute as the manager wants to add more topics in specific fields, for example in the field of rural issues, coastal, and public services. Until now, there is a new topic about Lifestyle, Environment, Opinion, Social Culture, and Technology. Those are topics that usually not considered "sexy" by the mainstream media. This makes the public space that is provided by Balebengong be interesting; even a simple topic could be news.

In Balebengong, the articles have also many positive themed appointed as a form of freedom of information itself. Jargon that "bad news is good news" does not apply in this local cyber media. Any information, any news is good news and has its own value. Residents are invited to continue working by sending this article to the media. For now, Balebengong is sufficient to provide a forum for citizens to play an active role in voicing his opinion. Seeing that the mainstream media in the usual raised the topic about the economy and politics, for Balebengong precisely topics such as living environment can also be used as headlines. Thus, this medium provides an understanding that it's fine to have a different perspective. Are the local cyber media that provide space for citizens to contribute trustworthy enough? Yes. This can be seen by the Media Guidelines attached Siber, widespread screening of articles before they are published, as well as check and re-check of the article by the editor. Is public space given enough for citizens to contribute? Yes. The researcher can deduce that the public space given is quite adequate, just not many people who contributed articles. Is allowed free-ofdomination room for dialogue of political and economic power enough? Of course, it is. Can be seen from the opinions expressed by the citizens, of the articles urging the government (in Bali in particular), to refuse reclamation Benoa Bay, for example, or the article "Song of the Silenced" about imprisonment in the New Order. Do this media play an active role in the development of its citizens? Yes. There is one article that rose about citizen journalism training. There are some small banners that 
read "Together Towards Independent Media Balebengong.net" and "For Freedom of Information, Rights is" an appeal of this medium so that citizens be not only passive receivers of information but also aware of the media and even producing the news.

Does Balebengong provide enough space for the society contribute in the news production? It sure does. But they still have to manage how to make more people interested in sharing the news with them. Balebengong perhaps is only one small instrument in this democratic nation, but in order to balance the news and to be the real fourth pillar, the researcher thinks that Balebengong is already on the right path. It provides enough public spheres for the citizen to contribute.

\section{REFERENCES}

APJII. (2014). Press Release - Profil Terkini Internet Industri Indonesia. Retrieved July 30 ${ }^{\text {th }}, 2014$ from http://www.apjii.or.id/v2/read/content/info-terkini/213/press-releaseprofil-terkiniinternet-industri-ind.html

Allan, S., \& Thorsen, E. (2009). Citizen Journalism: Global Perspective. New York: Peter Lang Publishing, Inc.

Baxter, L. A., \& Babbie, E. R. (2004). The basics of communication research. CA: Belmont.

Galtung, J. (1999). State, Capital, and the Civil Society: The Problem of Communication. In R. Vincent, K. Nordenstreng and M. Traber (eds.), Towards Equity in Global Communication: MacBride Update. Cresskill, NJ: Hampton Press.

Habermas, J. (1991). The Structural Transformation of the Public Sphere: An Inquiry into a category of Bourgeo is Society. Translated by Thomas Burger with Frederick Lawrence. Cambridge, MA: MIT Press.

Lindawati, L. (2014). Mengeraskan Suara Desa: Studi Kasus Peran Media Lokal Online Dalam Mengarustamakan Wacana Desa Mandiri di Kabupaten Banyumas Jawa Tengah pada tahun 2013-2014. In Proceeding Indonesia Media Research Awards \& Summit (IMRAS) Tren Pola Konsumsi Media Di Indonesia. Jakarta: SPS Indonesia.

Lindlof, T. R., \& Taylor, B. C. (1995). Qualitative Communication Research Methods. California: SAGE Publication Ltd.

McQuail, D. (2005). McQuail's Mass Communication Theory. Fifth Edition. London, United Kingdom: Sage.

Monaghan, G. \& Tunney, S., eds. (2010). Web journalism: a new form of citizenship? In: Monaghan, G., \& Tunney, S., (eds.). Sussex Academic Press. ISBN 9781845192785

Muhajir, A., Sumberdana, A., \& Wedra, P. S. (2012). Perkembangan Media Daring dan Jurnalisme Warga. Sloka Institute. Warga Bicara Media: Sepuluh Cerita, Centre for Innovation Policy and Governance (CIPG) dan HIVOS Jakarta.

Muhajir, A. (2007, $8^{\text {th }}$ August). Sekilas Peta Media Cetak di Bali. Retrieved August $18^{\text {th }} 2015$ from http://balebengong.net/kabar-anyar/2007/08/08/sekilas-peta-media-cetak-di-bali.html 
Setianto, Y. P. (2010). Public Sphere and the New Media (How Democratization and Political Communication in the Internet Shape the Indonesian Society). Retrieved August $18^{\text {th }} 2015$ from https://yearrypanji.wordpress.com/2011/03/10/public-sphere-and-the-new-media-howdemocratization-and-political-communication-in-the-internet-shape-the-indonesian-society/.

Suparyo, Y., \& Bambang, M. (2011). Pewarta Warga. Yogyakarta: Combine Resource Institution.

Yunni, I. (2013, $12^{\text {th }}$ March). Jurnalisme Online Sering Dinilai Tak Serius. Retrieved August $17^{\text {th }}$ 2015 from http://nasional.tempo.co/read/news/2013/03/12/173466520/jurnalisme-onlinesering-dinilai-tak-serius 